\title{
Vinasse as a Sustainable Medium for the Production of Chlorella vulgaris UTEX 1803
}

\author{
Viviana Quintero-Dallos ${ }^{1}$, Janet B. García-Martínez ${ }^{2}{ }^{\mathbb{D}}$, Jefferson E. Contreras-Ropero ${ }^{2}$, \\ Andrés F. Barajas-Solano ${ }^{2}$, Crisostomo Barajas-Ferrerira ${ }^{3}$, Roberto Lavecchia ${ }^{4}$ and \\ Antonio Zuorro ${ }^{4, * \mathbb{D}}$ \\ 1 Department of Environmental Engineering, Universidad Mariana, Calle 18 No. 34-104, Pasto 520002, \\ Colombia \\ 2 Department of Environmental Sciences, Universidad Francisco de Paula Santander, Av. Gran Colombia No. \\ 12E-96, Cúcuta 540003, Colombia \\ 3 Department of Chemical Engineering, Universidad Industrial de Santander, Cra 27 Calle 9, \\ Bucaramanga 680002, Colombia \\ 4 Department of Chemical Engineering, Materials and Environment, Sapienza University, Via Eudossiana 18., \\ 00184 Roma, Italy \\ * Correspondence: antonio.zuorro@uniroma1.it
}

Received: 18 May 2019; Accepted: 28 June 2019; Published: 24 July 2019

\begin{abstract}
This study investigates distillery wastewater, commonly known as vinasse, as a potential culture medium for the production of Chlorella vulgaris and its most relevant metabolites. The effect of vinasse concentration on the composition of the biomass (proteins, carbohydrates, and lipids) was evaluated in treatments performed in 6-L tubular air-lift reactors. The reactors were operated at $25^{\circ} \mathrm{C}$ for 18 days, in total darkness, under a continuous flow of air. Results showed a rapid growth of microalgae in the first ten days, when an average production of $0.87 \mathrm{~g} / \mathrm{L}$ was reached. Then, the daily biomass productivity began to decrease, up to an average value of $11.8 \mathrm{~g} / \mathrm{L}$ at the 16 th day. For all treatments, there was a significant reduction in the concentration of most metabolites in the first eight days. This was likely due to the adaptation of the biomass to the new conditions, with a transition from autotrophic to heterotrophic metabolism. From the 10th day, the concentration of metabolites in the biomass began to increase, reaching a nearly constant value at the 16 th day. The observed maximum concentrations ( $\% w / w)$ were: $48.95 \%$ proteins, $2.88 \%$ xylose, $7.82 \%$ glucose, $4.54 \%$ arabinose, $8.28 \%$ fructose, and $4.82 \%$ lipids. These values were only marginally affected by the type of treatment. Overall, the results obtained suggest that vinasse is a promising and sustainable medium for the growth of $C$. vulgaris and the production of valuable metabolites.
\end{abstract}

Keywords: distillery wastewater; vinasse; heterotrophic cultures; biorefinery; Chlorella vulgaris

\section{Introduction}

Large-scale production of wastewater is an inevitable consequence of contemporary societies. It leaves a trace on global biochemical cycles, mainly nitrogen, and phosphorus [1], as well as high concentrations of carbon and other nutrients. This has significantly reduced the self-purification capacity of natural water bodies [2,3]. As a result, several environmental regulations have been established to control this problem and regulate the levels of organic load, nitrogen, and phosphorus in the treated water [4].

The bioethanol industry produces large volumes (12-14 liters per liter of ethanol) of a wastewater known as vinasse [5]. Its characteristics depend on various factors such as variety and maturation degree of sugarcane, efficiency of the fermentation process and the conditions of the distillation 
process [6]. It is an acidic effluent ( $\mathrm{pH} 3-5)$ with high chemical and biochemical oxygen demands (COD: $60-134 \mathrm{~g} / \mathrm{L}$, BOD: 16-96 g/L) and average contents of nitrogen, phosphorus, and potassium equal to $0.55-4.2 \mathrm{~g} / \mathrm{L}, 0.13-3.03 \mathrm{~g} / \mathrm{L}$, and $2-17.5 \mathrm{~g} / \mathrm{L}$, respectively. Furthermore, the presence of phenolic compounds and melanoidins gives an intense coloration to vinasse, which is detrimental for living organisms and contributes to the deterioration of water quality [7].

In Colombia, Praj Delta T technology is used for the industrial production of bioethanol. This technology allows achieving about 1.6-2 liters of vinasse per liter of anhydrous alcohol produced [8]. In 2017, the production of this biofuel was around 367 million liters [9], generating about 920 million liters of vinasse, which was mainly used for fertigation of sugarcane crops. However, due to the accumulation of nutrients and the presence of heavy metals, this practice has been related to the increase in eutrophication of water bodies and soil instability [10].

National policies encourage the production and the use of liquid biofuels. According to resolution 40,185, from 2018 it is mandatory a bioethanol-gasoline mixture E10 in vehicles on the national territory consuming oxygenated fuel. This new guideline implies an expansion in biofuel production, and consequently, a considerable increase in the generation of vinasse, which can represent an environmental threat if not properly managed.

For the treatment of vinasse, both physicochemical and biological methods have been investigated. The former seek to eliminate organic load or chemical contaminants from water by membrane separation, solvent extraction, adsorption, or electrochemical treatments. However, these technologies exhibit inherent disadvantages, due to their high cost and the tendency to generate secondary pollutants [11].

An increasingly large number of studies confirm the ability of microalgae to remove phosphorylated substances [1]. These microorganisms can assimilate inorganic nitrogen and thus represent an excellent option for the bioremediation of wastewater [12]. In addition, from the knowledge of the different metabolites present in the biomass, it is possible to develop an integrated approach for their recovery in a facility called biorefinery [13].

The use of microalgae for the removal of pollutants and their transformation into biomass is one of the most promising technologies for water remediation [14-17]. In particular, these processes allow: (a) Nutrient removal effluents with high organic load; (b) treatment of industrial wastewaters with trace metals and acids; (c) $\mathrm{CO}_{2}$ sequestration; (d) transformation and degradation of xenobiotics; and (e) detection of toxic compounds by algae-based sensors.

Chlorella vulgaris has been proposed as a candidate for many of the above purposes due to its easy adaptability and rapid growth [18]. The treatment of vinasse by microalgae has been investigated over the last 20 years. Travieso et al. [19] used cultures of $C$. vulgaris SR/2, obtaining high nitrogen and phosphorus removal $(>85 \%)$ and a reduction in total solids of over $90 \%$. Valderrama et al. [20] showed that a sequential treatment by $C$. vulgaris and Lemma minuscule of a recalcitrant anaerobic distillery effluent allowed a reduction in organic matter and color of up to $52 \%$.

However, only since 2012 has the possibility of integrating the treatment of vinasse with the production of biofuels been investigated. Singh and Patel [11] showed that microalgae are promising candidates for the bioremediation of a large number of industrial effluents, including vinasses, and the combined production of components of interest to many industries. For example, Liu et al. [21] evaluated the use of sugarcane molasses as a carbon source for C. zofingiensis to obtain astaxanthins in addition to lipids for the production of biofuels. In 2016, Dos Santos et al. [22] proposed a two-stage process $(12: 12 \mathrm{~h}$ ) for the production of Spirulina maxima. In the first $12 \mathrm{~h}$, the microalgae were grown under autotrophic conditions (light plus $\mathrm{CO}_{2}$ ); in the second stage, the medium was enriched with vinasse. On the seventh day of each cycle, the biomass concentration at the end of the two stages was $0.495 \mathrm{~g} / \mathrm{L}$ and $0.609 \mathrm{~g} / \mathrm{L}$, respectively, and the protein content was $74.3 \%$ and $77.3 \%$ $(w / w)$. Santana et al. [23] investigated the growth of forty microalgae strains in sugarcane vinasse at different concentrations. Two of these strains, Micractinium sp. Embrapa|LBA32 and C. biconvexa Embrapa|LBA40, resulted in very high biomass productivity (around $180 \mathrm{mg} / \mathrm{L}$ per day) when grown in an airlift flat-plate photobioreactor. Proteins and carbohydrates were the major classes of components 
of microalgae biomass. Glucose was the main monosaccharide detected, ranging between $46 \%$ and $76 \%$ of the total carbohydrate content.

From the above considerations, it clearly emerges that a biorefinery approach combining microalgae cultivation with the biological degradation of vinasse can be a sustainable option for the production of value-added compounds for the biofuel and other sectors. However, due to its chemical composition, high organic content and low $\mathrm{pH}$, not all microalgae strains are able to grow in media containing vinasses. The main objective of this study was to evaluate whether the C. vulgaris strain UTEX 1803 could be grown in a culture medium supplemented with vinasse. This strain was selected because of its ability to grow in wastewater and its relatively high productivity of valuable metabolites, such as proteins, carbohydrates, and lipids. We were also interested in determining the biomass productivity and the evolution of the main microalgae components during the investigated treatments.

\section{Materials and Methods}

\subsection{Vinasse Production}

The vinasse used was obtained from the fermentation of molasses in the Laboratory of Chemical Processes at Universidad Industrial de Santander. For the fermentation process, $45 \mathrm{~kg}$ of commercial molasses were diluted in $151 \mathrm{~L}$ of water until reaching approximately $18^{\circ}$ Brix. The mixture was pasteurized at $80^{\circ} \mathrm{C}$ for $1 \mathrm{~h}$, then it was cooled to $40^{\circ} \mathrm{C}$ and the $\mathrm{pH}$ was adjusted to 4.2 by addition of sulfuric acid ( $95 \mathrm{wt} \%)$. The inoculum was prepared using $20 \mathrm{~L}$ of the mixture, to which ammonium chloride (144 g), magnesium sulfate ( $24 \mathrm{~g})$, urea $(24 \mathrm{~g})$, phosphate rock $(10 \mathrm{~g})$, and $500 \mathrm{~g}$ of commercial yeast Saccharomyces cerevisiae (Levapan, Colombia) were added. The inoculum was transferred to the tank together with the other diluted molasses. After $1 \mathrm{~h}$ aeration, the tank was covered to allow the fermentation process to proceed. The process was carried out for three days. Then, the mixture was evaporated by an evaporator operating at $94{ }^{\circ} \mathrm{C}$ in two stages, each lasting $210 \mathrm{~min}$.

\subsection{Vinasse Characterization and Nutrient Consumption}

Once obtained, the vinasses were assayed for total nitrogen, sodium, potassium, phosphorus and organic carbon. Other parameters such as alcoholic degree and the concentration of total sugars and solids were also determined. Total antioxidants content was assessed following procedure of Zuorro et al. [24,25]. Total nitrogen (TN) was evaluated by the Kjeldahl method; according to SM 4500-N (BUCHI, Flawil, Switzerland). Sodium and potassium were determined by atomic absorption, according to SM 3111 B (Thermo Fisher Scientific, Waltham, MA, USA) and EPA 3050 (Thermo Fisher Scientific, Waltham, MA, USA), respectively. Phosphorus was determined spectrophotometrically by SM 4500-P C (Thermo Fisher Scientific, Waltham, MA, USA) and total organic carbon (TOC) by NTC 5167 (Thermo Fisher Scientific, Waltham, MA, USA). These measurements were made at the Laboratory of Technical Consultations, Universidad Industrial de Santander (Colombia). Finally, sugar content (AOAC 932.14), total solids (AOAC 925.23), and alcoholic degree (ICONTEC 74) were determined by the Food Laboratory CICTA of Universidad Industrial de Santander.

\subsection{Inoculum Preparation}

Chlorella vulgaris UTEX 1803 was obtained from the UTEX collection (Austin, TX, USA). The alga was grown in in tubular glass reactors with a culture volume of $2 \mathrm{~L}$ containing Bold's Basal Medium [26]. Each reactor was equipped with a bubble aeration system for the injection of air with $1 \%(v / v) \mathrm{CO}_{2}$ at a flow-rate of $0.6 \mathrm{~L} \mathrm{~min}^{-1}$.

\subsection{Microalgae Cultivation}

Tubular 6-L air-lift reactors with a culture volume of $5 \mathrm{~L}$ were used. The reactors were equipped with a bubble aeration system for the injection of air at a flow-rate of $0.6 \mathrm{~L} \mathrm{~min}^{-1}$. The temperature was $25 \pm 1{ }^{\circ} \mathrm{C}$ and the $\mathrm{pH}$ was not controlled. Each reactor was coated with an aluminum foil to provide a 
fully dark environment over the $24 \mathrm{~h}$ period. To test the effect of vinasse on microalgae growth and composition, different dilutions of inoculum in vinasse were made (Tables 1-3). Each treatment was carried out in triplicate for 18 days.

Table 1. Culture media composition.

\begin{tabular}{cccccc}
\hline Treatment & Microalgae $(\mathbf{m L})$ & Vinasse $(\mathbf{m L})$ & Water $(\mathbf{m L})$ & $\begin{array}{c}\text { Final Vinasse } \\
\text { Concentration }(\mathbf{\%} \boldsymbol{v} / \boldsymbol{v})\end{array}$ & $\begin{array}{c}\text { Final } \\
\text { Volume }(\mathbf{m L})\end{array}$ \\
\hline CM1 & 1250 & 375 & 3375 & 10 & 5000 \\
CM2 & 1250 & 1875 & 1875 & 25 & 5000 \\
CM3 & 1250 & 3750 & 0 & 75 & 5000 \\
\hline
\end{tabular}

Table 2. Inoculation of diluted C. vulgaris in vinasse.

\begin{tabular}{cccc}
\hline Treatment & Microalgae $(\mathbf{m L})$ & Vinasse $(\mathbf{m L})$ & Final Volume $(\mathbf{m L})$ \\
\hline D1 & 1250 & 3750 & 5000 \\
D2 & 500 & 4500 & 5000 \\
\hline
\end{tabular}

Table 3. Inoculation of concentrated C. vulgaris in vinasse.

\begin{tabular}{cccc}
\hline Treatment & Microalgae $(\mathbf{g})$ & Vinasse $(\mathbf{m L})$ & Final Volume $(\mathbf{m L})$ \\
\hline C1 & 1 & 5000 & 5000 \\
C2 & 2 & 5000 & 5000 \\
C3 & 3 & 5000 & 5000 \\
\hline
\end{tabular}

\subsection{Quantification of Biomass Growth and Biomass Components}

Several methods are available in the literature for measuring biomass growth. The most widely used procedures include cell counting, absorbance or turbidity measurements, dry weight determination and quantification of some growth-related metabolites such as chlorophyll [27]. We used a dry-weight method. In particular, every two days, a 10-mL sample was removed from each reactor, centrifuged at $3400 \mathrm{rpm}$ for $20 \mathrm{~min}$ and the supernatant was withdrawn. The solid fraction was resuspended in $10 \mathrm{~mL}$ of distilled water, filtered on pre-combusted $\mathrm{CF} / \mathrm{C}$ glass fiber filters and dried overnight at $60{ }^{\circ} \mathrm{C}$ in an oven containing a bed of silica gel.

The main biomass components were quantified every two days. Protein content was determined by the Kjeldahl method using a nitrogen conversion factor of 6.25 [27]. Lipids were determined by the modified Bligh and Dyer method described by Barajas-Solano et al. [28]. Total carbohydrates were evaluated by the colorimetric method of Dubois et al. [29] modified by Jerez-Mogollón et al. [30]. This procedure is based on the spectrophotometric detection of the complex formed by the reaction of carbohydrates with phenol in concentrated sulfuric acid.

\section{Results and Discussion}

\subsection{Vinasse Characterization}

Vinasse is mainly composed of organic matter, potassium, sulfur, magnesium, nitrogen, and calcium, in amounts depending on the effluent source. It also contains phenolic dyes, caramel and melanoidins, which are responsible for its characteristic dark color. Studies carried out by Gloria and Filho [31], showed that vinasse from molasses had higher contents of organic matter and mineral elements. Table 4 shows the concentration ranges for the main compounds identified in the vinasse used as culture medium in this study. 
Table 4. Chemical composition of vinasse.

\begin{tabular}{cc}
\hline Nutrients & Concentration Range \\
\hline Phosphorus $(\mathrm{g} \mathrm{P} / \mathrm{L})$ & $0.055-0.057$ \\
Potassium $(\mathrm{g} \mathrm{K} / \mathrm{L})$ & $24.60-24.62$ \\
Sodium $(\mathrm{g} \mathrm{Na} / \mathrm{L})$ & $0.57-0.58$ \\
Total nitrogen $(\mathrm{g} \mathrm{N} / \mathrm{L})$ & $2.32-2.38$ \\
Total organic carbon $(\mathrm{g} / \mathrm{L})$ & $2.13-2.14$ \\
Alcoholic degree $(\%$ v/v) & $0.05-0.07$ \\
Total sugars $(\%)$ & $11.3-11.5$ \\
Total solids $(\%)$ & $12.4-12.7$ \\
\hline
\end{tabular}

\subsection{Biomass Production}

The biomass growth rates determined in the investigated treatments are reported in Table 5.

Table 5. Biomass growth rates in the eight treatments.

\begin{tabular}{|c|c|}
\hline Treatment & Growth Rate $\left(\mathrm{g} \mathrm{L}^{-1} \mathrm{~d}^{-1}\right)$ \\
\hline CM1 & $0.05 \pm 0.02$ \\
\hline CM2 & $0.15 \pm 0.04$ \\
\hline CM3 & $0.24 \pm 0.06$ \\
\hline D1 & $0.64 \pm 0.06$ \\
\hline D2 & $0.64 \pm 0.03$ \\
\hline $\mathrm{C} 1$ & $0.58 \pm 0.04$ \\
\hline $\mathrm{C} 2$ & $0.72 \pm 0.05$ \\
\hline C3 & $0.67 \pm 0.08$ \\
\hline
\end{tabular}

Figure 1 displays the time variation of biomass production at different vinasse concentrations. As can be seen, the highest growth rate was achieved using undiluted vinasse $(75 \% v / v)$, which led to a biomass concentration of $5.11 \mathrm{~g} / \mathrm{L}$ after 18 days. This is probably due to the higher concentration of nutrients in the medium.

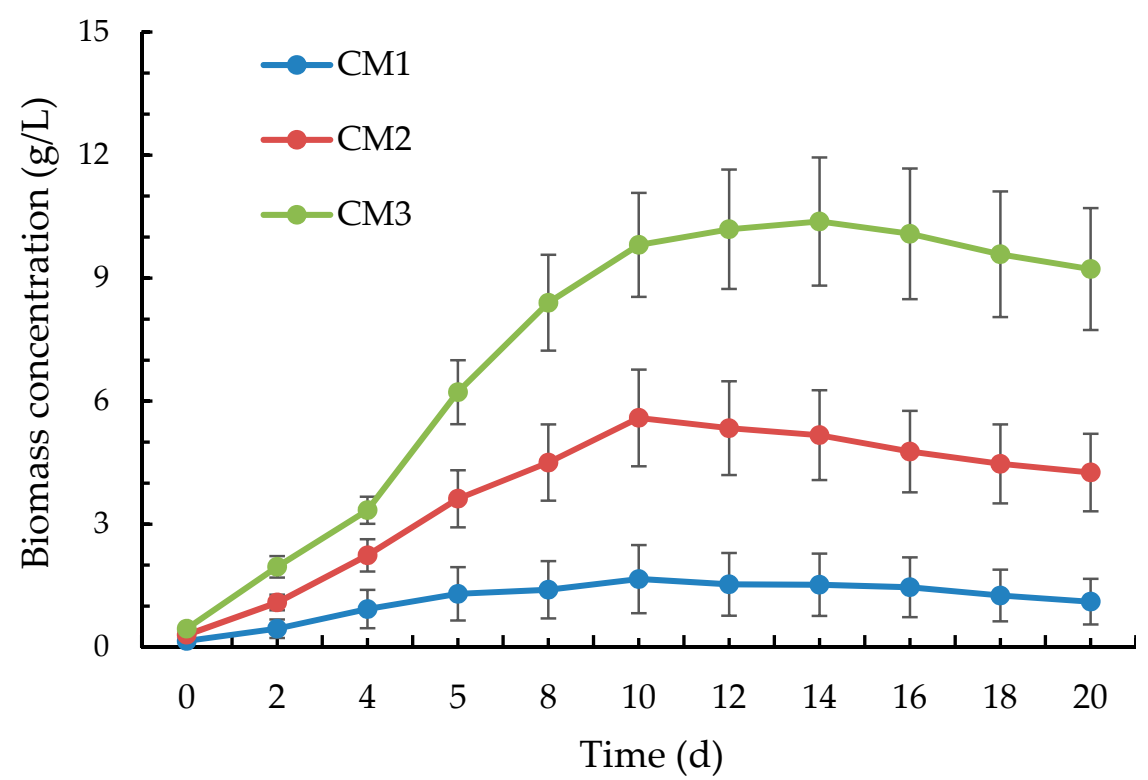

Figure 1. Production of biomass in culture media with different concentrations of vinasse.

In Figure 2, the $\mathrm{pH}$ changes in media with different concentrations of vinasse are shown. A first point to note is that in all media, including the most acidic one (CM3), a steady-state $\mathrm{pH}$ value close to seven was reached. This can be attributed to different factors, such as the uptake of acidic vinasse 
components by the microalgae, the production of extracellular compounds capable of complexing or reacting with those components and the continuous injection of air in the medium, which contributes to the removal of the carbon dioxide produced during cellular respiration. Another important consideration to be made is that, despite the optimum $\mathrm{pH}$ for the growth of the investigated microalgal strain is around 7-7.5, the biomass is capable of growing even at $\mathrm{pH}$ value close to $4-4.5$. This is what was observed during the first four days of growth in $\mathrm{CM} 3$, the medium with the highest concentration of vinasse and hence of nutrients. Since the growth rate of microalgae depends on both the $\mathrm{pH}$ and the amount of nutrients, the above results suggest that the reduction in biomass growth due to the low $\mathrm{pH}$ value is compensated for by the increase resulting from the higher amount of nutrients.

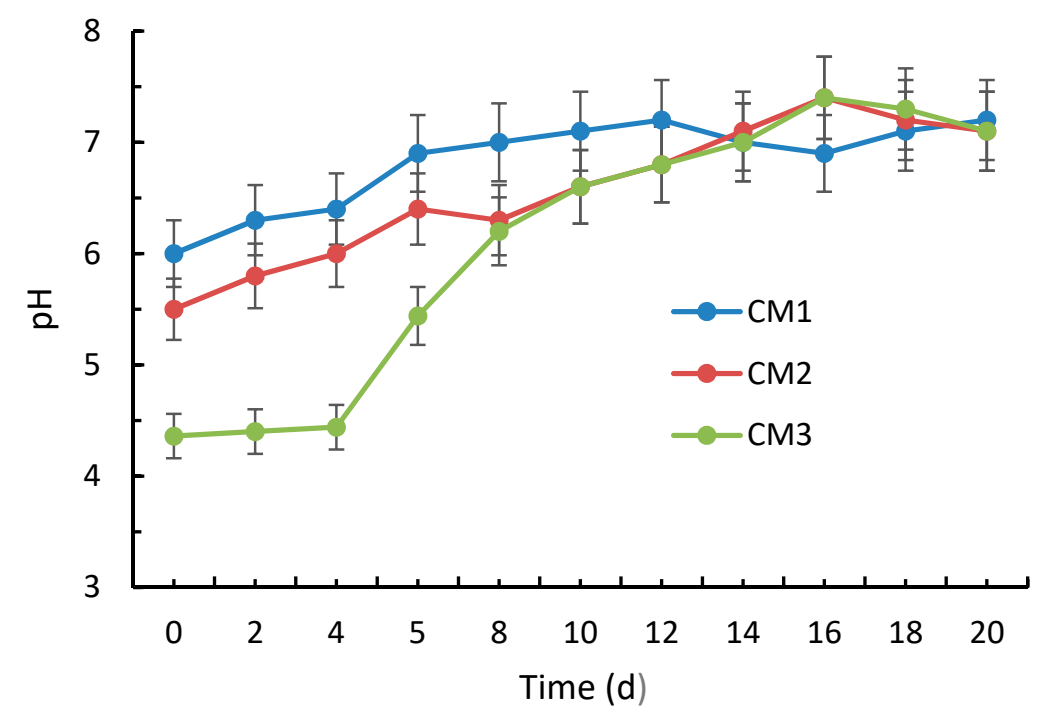

Figure 2. $\mathrm{pH}$ changes during biomass production in media with different concentrations of vinasse.

The five treatments performed at different biomass/vinasse ratios (see Tables 2 and 3) gave the results presented in Figure 3. The trends were qualitatively similar for all treatments, with a progressive increase in biomass concentration during the first $8-10$ days, followed by a nearly stationary phase. At day 18 , treatment $\mathrm{C} 2$ resulted in the highest biomass concentration $(8.7 \mathrm{~g} / \mathrm{L})$ and productivity $(0.48 \mathrm{~g}$ $\left.\mathrm{L}^{-1} \mathrm{~d}^{-1}\right)$, while the lowest values $\left(6.1 \mathrm{~g} / \mathrm{L}\right.$ and $\left.0.34 \mathrm{~g} \mathrm{~L}^{-1} \mathrm{~d}^{-1}\right)$ were observed for $\mathrm{C} 1$.

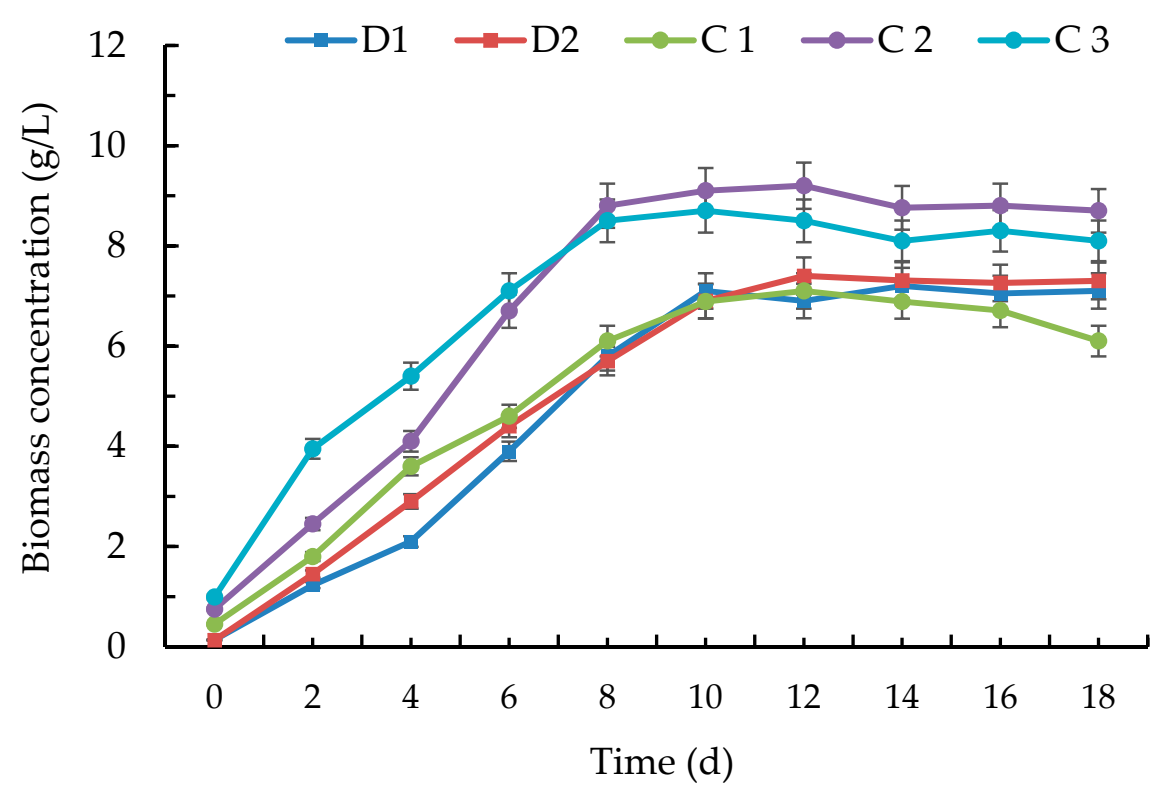

Figure 3. Biomass production during the five treatments (see Tables 2 and 3). 
In the present work, C. vulgaris was not affected by the concentration of the vinasse evaluated. Liu et al. [21] used industrial cane molasses as a carbon source for the production of Chlorella zofingiensis. When the microalgae were subjected to an ion-exchange pretreatment to remove metal ions, a biomass productivity of $1.55 \mathrm{~g} \mathrm{~L}^{-1} \mathrm{~d}^{-1}$ was obtained. This value was slightly higher than that found using glucose instead of molasses. At higher nutrient levels, the production of biomass was decreased, which was attributed to substrate inhibition. Doucha and Livansky [32] obtained up to $117.2 \mathrm{~g} / \mathrm{L}$ of C. vulgaris under heterotrophic conditions with glucose as carbon and energy source. This high production of biomass was achieved with an initial glucose concentration of $65 \mathrm{~g} / \mathrm{L}$. However, the specific growth rate decreased approximately linearly with increasing glucose concentration, which again was attributed to substrate inhibition phenomena. It was also shown that the content of some microalgae components, such as proteins, chlorophylls, and $\beta$-carotene, could be increased by keeping the biomass in the fermenter for an additional time after the cell growth was arrested due to glucose deficiency. Candido and Lombardi [33] used conventional and biodigested vinasses pretreated by filtration or centrifugation as a culture medium for $C$. vulgaris. The highest growth rates were obtained in $60 \%$ $(v / v)$ filtered conventional and $80 \%(v / v)$ biodigested vinasses. The authors pointed out that filtration or centrifugation are essential treatments to be performed on vinasses before their use as a culture medium in order to eliminate toxic components and improve light penetration into the medium. In another study on a novel strain of Micractinium sp., sugarcane vinasse was used as a nutrient source for the heterotrophic and mixotrophic growth of the biomass [34]. Mixotrophic cultures resulted in higher specific growth rates and productivities, compared to the heterotrophic ones. For both of them, the highest biomass concentration and productivity were obtained with $10 \%(v / v)$ vinasse. Higher vinasse concentrations caused a decrease in microalgal growth, which was ascribed to toxic effects of vinasse components and/or light intensity reduction due to their presence. These considerations provide a possible explanation for the results of the present study displayed in Figure 3. In particular, there appears to be an optimal vinasse concentration (C2 treatment) at which the negative effects on biomass growth and productivity due to the presence of inhibiting and/or toxic compounds are balanced by the positive effects resulting from the higher nutrient levels.

\subsection{Nutrient Consumption by the Microalgae}

Figure 4 shows the consumption of the primary nutrients (phosphorus, potassium, and nitrogen) and carbon present in vinasse by the microalgae in the $\mathrm{C} 2$ treatment. This consumption is strictly related to the amount of biomass produced.

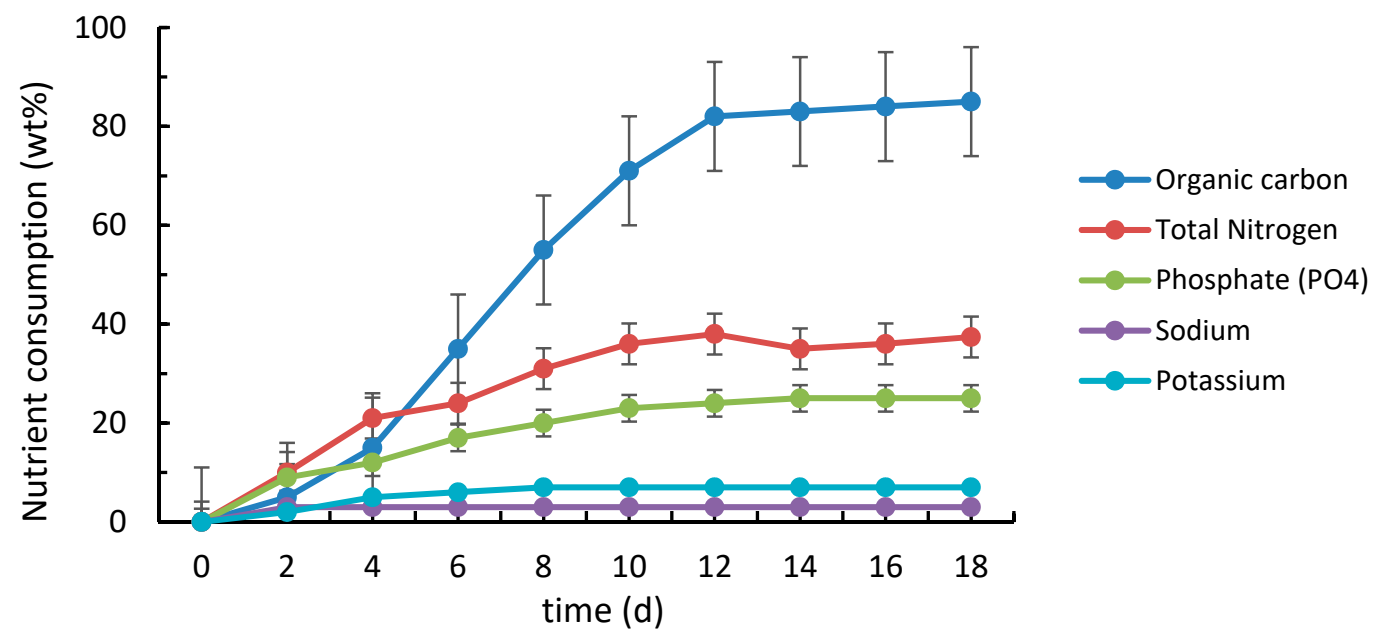

Figure 4. Nutrient consumption by the microalgae in the $\mathrm{C} 2$ treatment.

Carbon is the major component of the biomass, reaching up to $50 \%$ of the total weight [35]. At day 18 , it was reduced by about $85 \%$. The amount of nitrogen consumed was approximately $38 \%$, 
corresponding to about $950 \mathrm{mg} / \mathrm{L}$. Travieso et al. [36] tested the suitability of pretreated vinasse as a culture medium for $C$. vulgaris in a continuous photobioreactor. They found a total nitrogen reduction of up to $1000 \mathrm{mg} / \mathrm{L}$, which is very close to that of the present study, although the vinasse we used was not subjected to any pretreatment. From Figure 4 , it can also be seen that $25 \%$ of all phosphorous present in the vinasse was consumed by the biomass at day 18, which corresponds to $14.25 \mathrm{mg} / \mathrm{L}$ of its initial content. Similar results were obtained by Valderrama et al. [20] using C. vulgaris and pretreated vinasse.

In vinasse, two carbon sources are present: Ethanol and residual sugars. They can be consumed through both autotrophic and heterotrophic pathways (Figure 5). Due to its low content $(0.05-0.07 \%$ $v / v)$, ethanol can be expected to be consumed very quickly by $C$. vulgaris without exerting any inhibitory effect on it. Regarding sugars, their content decreased from $11.3-11.5 \%$ to about $6 \%$ in the first eight days. Then, they increased up to $8.3 \%$ at day 18 . This increase, and also that observed for total solids, can be explained by the secretion of exopolysaccharides by the microalgae. As is known, depending on the growth phase and culture conditions, microalgae can produce biofilms containing carbohydrates and proteins $[37,38]$.

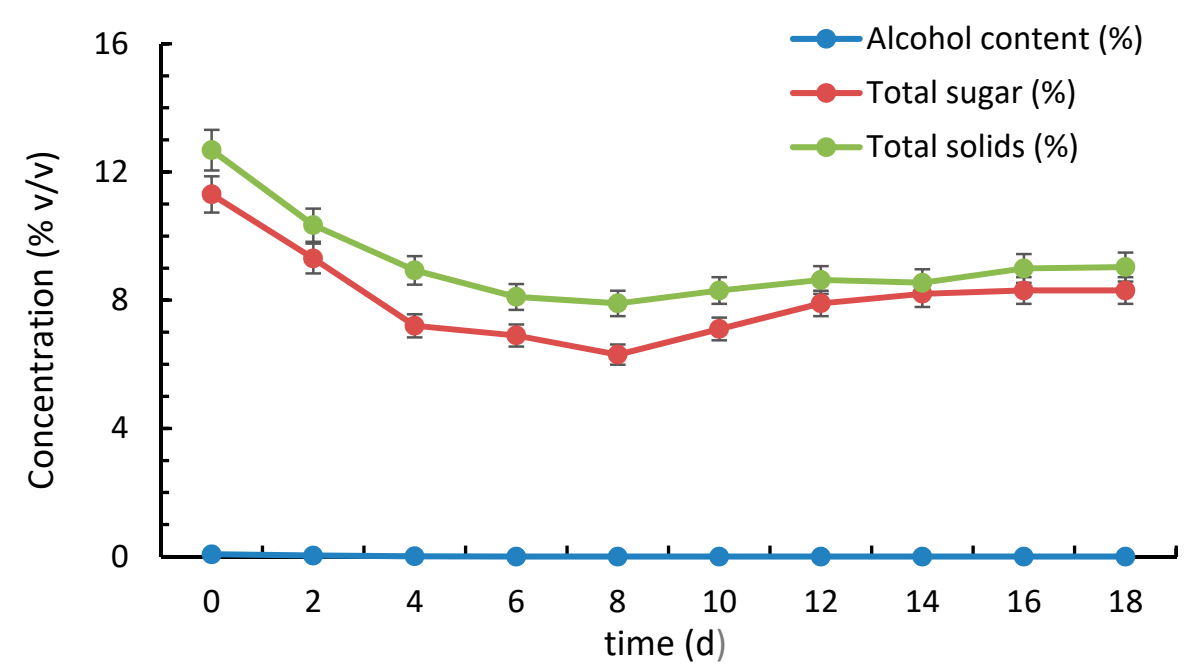

Figure 5. Variation in total solids, total sugars and alcohol content in vinasse in the $\mathrm{C} 2$ treatment.

\subsection{Biomass Composition}

During each of the five investigated treatments (D1, D2, C1, C2, C3, C4, and C5) the biomass was characterized in terms of protein, carbohydrate, and lipid content. The results of measurements performed at intervals of two days are shown in Figure 6. 

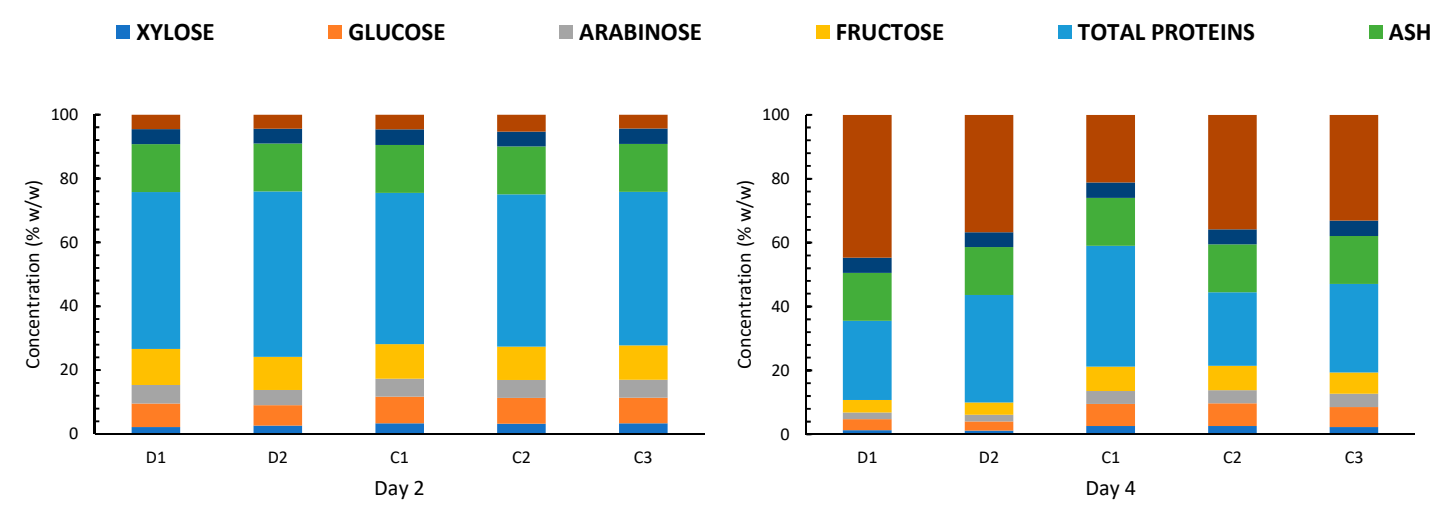

- TOTAL LIPIDS

— OTHER METABOLITES
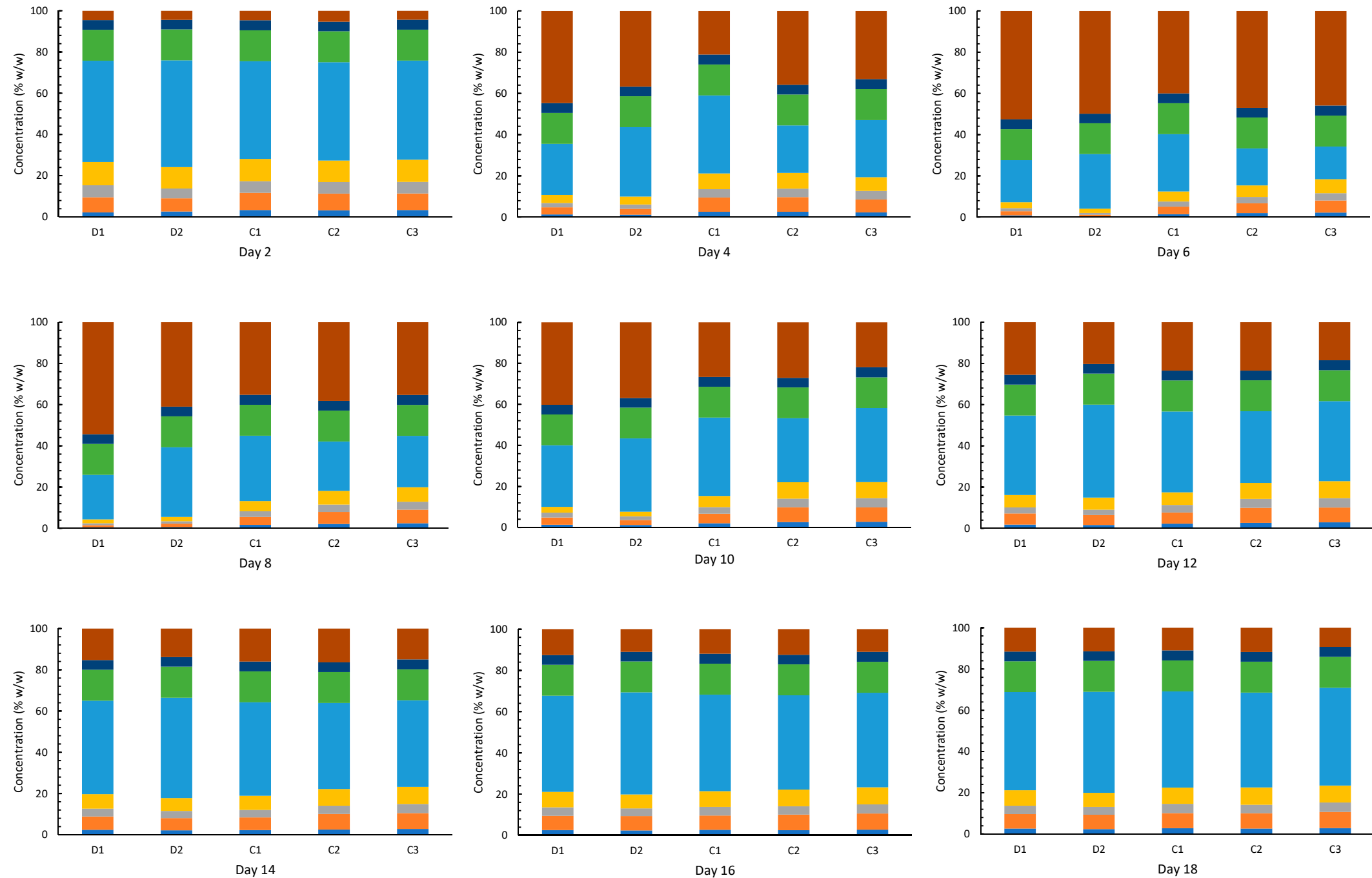

Figure 6. Changes in the composition of C. vulgaris over the 18-day period of treatments with diluted (D1, D2) and concentrated (C1, C2, C3) biomass. 
Regarding the protein content, in all treatments a decrease was observed during the first six days. After this period, the amount of proteins began to increase until reaching a nearly constant value around the 14th day. At the 6th day, the following values were determined (\%w/w): $20.47 \%$ (D1), $26.37 \%(\mathrm{D} 2), 27.78 \%(\mathrm{C} 1), 17.90 \%(\mathrm{C} 2)$, and $15.90 \%$ (C3), while at the 18th day they were, respectively, equal to: $47.53 \%, 48.95 \%, 46.67 \%, 45.95 \%$, and $47.37 \%$. Changes in the protein content occurring during the first ten days can be attributed to a progressive shift of the metabolism from photoautotrophic to mixotrophic and to fully heterotrophic. In a study by Coca et al. [39], Spirulina platensis was grown in an airlift photobioreactor using a culture medium supplemented with 1 or $2 \mathrm{~g} / \mathrm{L}$ of beet vinasse. At the lowest vinasse concentration, both biomass and protein productivities were increased, while at higher concentration they showed a decrease, although the protein content of the biomass remained relatively stable, at about $53 \%$. In another study on Spirulina maxima grown in media supplemented with $3 \%$ $(v / v)$ sugarcane vinasse under cyclic two-stage cultivation (12-h autotrophic conditions followed by 12-h fed-batch heterotrophic conditions during the dark phase), a protein content ranging from 74.3 to $77.3 \%(w / w)$ was determined [22]. In yet another study on the cultivation of selected microalgae strains in sugarcane vinasse, a protein content between 34 and $40 \%(w / w)$ was obtained [23]. Furthermore, an inverse correlation was observed between protein and carbohydrate contents. According to the authors, this could be related to the high availability of a nitrogen source in vinasses, which would favor the accumulation of proteins over that of carbohydrates.

As for the carbohydrate content, the values obtained in the different treatments were very close to each other. This was particularly evident in cultures inoculated with diluted microalgae (D1 and D2). The content of all monosaccharides decreased during the first eight days, reaching a minimum on the 6th day (C1, C2, and C3) or the 8th day (D1 and D2). This reduction may be a reflection of the switch of autotrophically grown microalgae to heterotrophic metabolism. After the 10th day, the amount of these metabolites showed a progressive increase, reaching a maximum around the 16th day. Xylose was the compound present at the lowest concentration in the biomass. At day 8 , the following values were determined (\% w/w): $0.53 \%(\mathrm{D} 1), 0.61 \%(\mathrm{D} 2), 1.43 \%(\mathrm{C} 1), 1.91 \%(\mathrm{C} 2)$, and $2,2 \%(\mathrm{C} 3)$. From the 10th to the 18th day, the concentration of xylose increased and stabilized to $2.57 \%$ (D1), $2.39 \%$ (D2), $2.85 \%$ (C1), 2.64\% (C2), and 2.88\% (C3). Glucose and fructose were the major monosaccharides in the biomass. As observed for the other metabolites, they reached their minimum during the first eight days. The minimum glucose levels were (\%w/w): $1.02 \%$ (D1), $1.71 \%$ (D2), 3.70\% (C1), $4.82 \%$ (C2), and 5.84\% (C3). From the 10th day, this metabolite began to increase, reaching a value of $7.07 \%$ (D1), $6.97 \%$ (D2,) $7.29 \%(\mathrm{C} 1), 7.40 \%(\mathrm{C} 2)$, and $7.82 \%$ (C3). During this time period, the measured standard deviations ranged from $2.13 \%$ to $0.034 \%$ on the 18 th day. Fructose was the monosaccharide with the highest concentration in the biomass. Its maximum level was reached at day 16, although a decrease in concentration was observed during the first eight days. The minimum concentration values were (\%w/w): $1.83 \%(\mathrm{D} 1), 2.13 \%(\mathrm{D} 2), 4.94 \%(\mathrm{C} 1), 5.62 \%(\mathrm{C} 2)$, and $6.77 \%(\mathrm{C} 3)$ with a maximum standard deviation of 2.46 at day 8 . The maximum concentration values were ( $\% w / w): 7.52 \%$ (D1), $6.85 \%(\mathrm{D} 2), 7.87 \%(\mathrm{C} 1), 8.41 \%(\mathrm{C} 2)$, and $8.28 \%(\mathrm{C} 3)$, with a standard deviation at the 18 th day of $0.63 \%$. Arabinose levels showed the same qualitative changes observed for the other carbohydrates. Its minimum concentration occurred at day 8 , when the following values were determined $(\% w / w)$ : $0.94 \%(\mathrm{D} 1), 0.88 \%$ (D2), $2.39 \%(\mathrm{C} 1), 3.09 \%$ (C2), and 3.57\% (C3), with a standard deviation of $1.37 \%$ at the eighth day. From the 10th day, the concentration began to increase, reaching a maximum at the 18th day, when the following values were observed (\%w/w): $4.07 \%$ (D1), 3.78\% (D2), $4.50 \%$ (C1), $4.17 \%$ (C2), and $4.54 \%$ (C3).

In previous studies on different strains of $C$. vulgaris carbohydrate levels ranging between $41 \%$ and $55 \%$ were found $[18,40,41]$. Monosaccharides were up to $22 \%$ of the total biomass on day 18 , with a biomass production of $13.17 \mathrm{~g} / \mathrm{L}$. The presence of carbohydrates in low amount in the biomass is likely due to the high level of nitrogen in the culture medium, as these two quantities appear to be inversely related [40,42]. Jerez-Mogollón et al. [30] obtained a maximum content of xylose of $9.70 \%(w / w)$ in a 
culture of C. vulgaris UTEX 1803 enriched with sodium acetate. In the same study, a glucose content of up to of $9.30 \%(w / w)$ was determined [30].

Finally, from Figure 6 it can be seen that lipids were the metabolites at the lowest concentration, their amounts (\%w/w) being: 1.72\% (D1), 1.63\% (D2), 1.79\% (C1), 1.67\% (C2), and 1.83\% (C3). Similar low levels of these compounds were found by Engin et al. [34], who used a culture medium supplemented with vinasse to grow Micractinium sp., although in other studies significantly higher lipid contents were achieved $[43,44]$. However, as already mentioned, there seems to be an inverse correlation between protein accumulation in algal biomass and carbohydrates and/or lipid content [23], consistently with the results of the present study.

Overall, it can be concluded that incorporation of appropriate amounts of vinasse in culture media is not only an effective remediation strategy for the treatment of this effluent but also an attractive alternative for the production of valuable metabolites such as carbohydrates and proteins from C. vulgaris $[45,46]$. This approach can be included in the wider context of the sustainable reuse of waste materials for reducing the consumption of natural resources and the environmental impact of human activities [47-49]. Furthermore, it has the potential of being easily transferred to the industrial scale, as the conditions necessary for the heterotrophic growth of microalgae are similar to those employed for the large-scale production of yeast and bacteria [50,51]. In principle, vinasse could be treated in either open or closed bioreactors, with suspended or non-suspended biomass [52]. The experience gained so far from similar systems suggests that a closed photobioreactor with a periodic harvesting of the biomass is the best option, as this reactor configuration allows better $\mathrm{pH}$ and temperature control, better mixing, higher cell densities, better protection against culture contamination, and lower evaporative losses, compared to the open one [53], and it will be optimized in a response surface methodology study [54].

\section{Conclusions}

The results of this study indicate that vinasse represents a suitable and effective medium for the growth of $C$. vulgaris UTEX 1803. The algal biomass can be used as a source of value-added compounds for food, nutraceutical, cosmetic, and biofuel applications. Concerning the inoculation of the strain, there appear to be no significant differences in the amount of metabolites produced by the biomass in the five treatments examined.

Future studies should be focused on the optimization of the treatment conditions for the vinasse-biomass system. Another important issue to be addressed is to evaluate whether the production of a specific metabolite or class of metabolites can be controlled by proper selection of process conditions.

Author Contributions: Conceptualization, J.E.C.-R. and A.Z.; Data curation, R.L.; Formal analysis, V.Q.-D. and C.B.-F.; Funding acquisition, V.Q.-D.; Investigation, V.Q.-D.; Methodology, J.B.G.-M., A.F.B.-S. and A.Z.; Project administration, C.B.-F.; Resources, V.Q.-D.; Software, J.B.G.-M.; Supervision, A.F.B.-S. and A.Z.; Validation, J.E.C.-R., A.F.B.-S. and A.Z.; Visualization, A.F.B.-S. and C.B.-F.; Writing-original draft, A.F.B.-S. and A.Z.; Writing-review \& editing, R.L. and A.Z.

Funding: This research was funded by Universidad Francisco de Paula Santander internal Research funding: FINU 44-2018 and The APC was funded by Universidad Mariana.

Acknowledgments: We would like to express our sincere gratitude to Universidad Francisco de Paula Santander for providing the equipment for this research and the Departamento Administrativo de Ciencia, Tecnología e Innovación COLCIENCIAS for the support to national PhD Doctorates through the Francisco José de Caldas scholarship program.

Conflicts of Interest: The authors declare no conflict of interest. 


\section{References}

1. Aslan, S.; Kapdan, I. Batch kinetics of nitrogen and phosphorus removal from synthetic wastewater by algae. Ecol. Eng. 2006, 28, 64-70. [CrossRef]

2. Boursier, H.; Béline, F.; Paul, E. Piggery wastewater characterization for biological nitrogen removal process design. Bioresour. Technol. 2005, 96, 351-358. [CrossRef] [PubMed]

3. Olguin, E.J.; Galicia, S.; Angulo-Guerrero, O.; Hernandez, E. The effect of low light flux and nitrogen deficiency on the chemical composition of Spirulina sp. (Arthrospira) grown on digested pig waste. Bioresour. Technol. 2001, 77, 19-24. [CrossRef]

4. Sheng, A.L.K.; Bilad, M.R.; Osman, N.B.; Arahman, N. Sequencing batch membrane photobioreactor for real secondary effluent polishing using native microalgae: Process performance and full-scale projection. J. Clean. Prod. 2017, 168, 708-715. [CrossRef]

5. Leme, R.M.; Seabra, J.E.A. Technical-economic assessment of different biogas upgrading routes from vinasse anaerobic digestion in the Brazilian bioethanol industry. Energy 2017, 119, 754-766. [CrossRef]

6. Tapie, W.A.D.; Prato-García, D.; Guerrero, H. Biodegradation of sugarcane vinasses by the white-rot fungi Pleurotus ostreatus in a packed bed reactor. Trop. Subtrop. Agroecosyst. 2016, 19, 145-150.

7. Hoarau, J.; Caro, Y.; Grondin, I.; Petit, T. Sugarcane vinasse processing: Toward a status shift from waste to valuable resource. A review. Water Proc. Eng. 2018, 24, 11-25. [CrossRef]

8. Incauca SAS. Informe de sostenibilidad 2016-2017. Available online: https://www.incauca.com/wp-content/ uploads/2018/04/Informe-Sostenibilidad-Incauca-2016-2017.pdf (accessed on 5 April 2019).

9. Fedebiocombustibles. Cifras Informativas del Sector Biocombustibles. Alcohol Carburante (Etanol Anhidro). Available online: http://www.fedebiocombustibles.com/nota-web-id-487.htm (accessed on 5 April 2019).

10. Rodrigues Reis, C.E.; Hu, B. Vinasse from sugarcane ethanol production: Better treatment or better utilization? Energy Res. 2017, 1-7. [CrossRef]

11. Singh, N.K.; Patel, D.B. Microalgae for Bioremediation of Distillery Effluent. In Farming for Food and Water Security; Lichtfouse, E., Ed.; Springer: Dordrecht, The Netherlands, 2012; pp. 83-109.

12. Salgueiro, J.L.; Perez, L.; Maceiras, R.; Sanchez, A.; Cancela, A. Bioremediation of wastewater using Chlorella vulgaris microalgae: Phosphorus and organic matter. Int. J. Environ. Res. 2016, 10, 465-470. [CrossRef]

13. González, A.; Kafarov, V. Microalgae based biorefinery: Issues to consider. Ciencia Tecnol. Fut. 2011, 4, 5-22.

14. Olguin, E.J. Phycoremediation: Key issues for cost-effective nutrient removal processes. Biotechnol. Adv. 2003, 22, 81-91. [CrossRef]

15. Ayala, J.F.; Bravo, B.P. Animal wastes media for Spirulina production. Algol. Stud. 1984, 36, 349-355. [CrossRef]

16. Costa, R.H.; Medri, W.; Perdomo, C.C. High-rate pond for treatment of piggery wastes. Water Sci. Technol. 2000, 42, 357-362. [CrossRef]

17. Jimenez-Perez, M.V.; Sanchez-Castillo, P.; Romera, O.; Fernandez-Moreno, D.; Perez-Martinez, C. Growth and nutrient removal in free and immobilized planktonic green algae isolated from pig manure. Enzyme Microb. Technol. 2004, 34, 392-398. [CrossRef]

18. Brennan, L.; Owende, P. Biofuels from microalgae-A review of technologies for production, processing, and extractions of biofuels and co-products. Renew. Sust. Energ. Rev. 2010, 14, 557-577. [CrossRef]

19. Travieso, L.; Benitez, F.; Dupeyrón, R. Algae growth potential measurement in distillery wastes. Bull. Environ. Contam. Toxicol. 1999, 62, 483-489. [CrossRef]

20. Valderrama, L.; Del Campo, C.; Rodriguez, C.; Bashan, Y.; de-Bashan, L. Treatment of recalcitrant wastewater from ethanol and citric acid production using the microalga Chlorella vulgaris and the macrophyte Lemna minuscula. Water Res. 2002, 36, 4185-4192. [CrossRef]

21. Liu, J.; Huang, J.; Jiang, Y.; Chen, F. Molasses-based growth and production of oil and astaxanthin by Chlorella zofingiensis. Bioresour. Technol. 2012, 107, 393-398. [CrossRef]

22. Dos Santos, R.R.; Araújo, O.D.Q.F.; de Medeiros, J.L.; Chaloub, R.M. Cultivation of Spirulina maxima in medium supplemented with sugarcane vinasse. Bioresour. Technol. 2016, 204, 38-48. [CrossRef]

23. Santana, H.; Cereijo, C.R.; Teles, V.C.; Nascimento, R.C.; Fernandes, M.S.; Brunale, P.; Campanha, R.C.; Soares, I.P.; Silva, F.C.P.; Sabaini, P.S.; et al. Microalgae cultivation in sugarcane vinasse: Selection, growth and biochemical characterization. Bioresour. Technol. 2017, 228, 133-140. [CrossRef] 
24. Zuorro, A.; Lavecchia, R.; Medici, F.; Piga, L. Use of cell wall degrading enzymes for the production of high-quality functional products from tomato processing waste. Chem. Eng. Trans. 2014, 38, 355-360. [CrossRef]

25. Zuorro, A.; Maffei, G.; Lavecchia, R. Effect of solvent type and extraction conditions on the recovery of phenolic compounds from artichoke waste. Chem. Eng. Trans. 2014, 39, 463-468. [CrossRef]

26. Andersen, R.A.; Berges, J.A.; Harrison, P.J.; Watanabe, M.M. Appendix A-Recipes for Freshwater and Seawater Media. In Algal Culturing Techniques; Andersen, R.A., Ed.; Elsevier Academic Press: Burlington, MA, USA, 2005; pp. 429-538.

27. Moheimani, N.R.; Borowitzka, M.A.; Isdepsky, A.; Sing, S.F. Standard Methods for Measuring Growth of Algae and Their Composition. In Algae for Biofuels and Energy; Borowitzka, M.A., Moheimani, N.R., Eds.; Springer: New York, NY, USA, 2013; pp. 265-284.

28. Barajas-Solano, A.; Guzmán-Monsalve, A.; Kafarov, V. Effect of carbon-nitrogen ratio for the biomass production, hydrocarbons and lipids on Botryoccus braunii UIS 003. Chem. Eng. Trans. 2016, 49, $247-252$.

29. DuBois, M.; Gilles, K.A.; Hamilton, J.K.; Rebers, P.A.; Smith, F. Colorimetric method for determination of sugars and related substances. Anal. Chem. 1956, 28, 350-356. [CrossRef]

30. Jerez-Mogollón, S.J.; Rueda-Quiñonez, L.V.; Alfonso-Velazco, L.Y.; Barajas-Solano, A.F.; Barajas-Ferreira, C.; Kafarov, V. Improvement of lab-scale production of microalgal carbohydrates for biofuel production. Ciencia Tecnol. Fut. 2012, 5, 103-116.

31. Glória, N.A.; Filho, O. Aplicação da vinhaça como fertilizante. Boletin Técnico do PLANALSUCAR 1983, 5, 5-38.

32. Doucha, J.; Livansky, K. Production of high-density Chlorella culture grown in fermenters. Appl. Phycol. 2012, 24, 35-43. [CrossRef]

33. Candido, C.; Lombardi, A.T. Growth of Chlorella vulgaris in treated conventional and biodigested vinasses. J. Appl. Phychol. 2017, 29, 45-53. [CrossRef]

34. Engin, I.K.; Cekmecelioglu, D.; Yücel, A.M.; Oktem, H.A. Evaluation of heterotrophic and mixotrophic cultivation of novel Micractinium sp. ME05 on vinasse and its scale up for biodiesel production. Bioresour. Technol. 2018, 251, 128-134. [CrossRef]

35. Bumbak, F.; Cook, S.; Zachleder, V.; Hauser, S.; Kovar, K. Best practices in heterotrophic high-cell-density microalgal processes: Achievements, potential and possible limitations. Appl. Microbiol. Biotechnol. 2011, 91, 31-46. [CrossRef]

36. Travieso, L.; Benítez, F.; Sánchez, E.; Borja, R.; León, M.; Raposo, F.; Rincón, B. Performance of a laboratory-scale microalgae pond for secondary treatment of distillery wastewaters. Chem. Biochem. Eng. 2008, 22, 467-473.

37. Flemming, H.C.; Wingender, J. The biofilm matrix. Nat. Rev. Microbiol. 2010, 8, 623-633. [CrossRef] [PubMed]

38. De Philippis, R.; Vincenzini, M. Exocellular polysaccharides from cyanobacteria and their possible applications. FEMS. Microbiol. Rev. 1998, 22, 151-175. [CrossRef]

39. Coca, M.; Barrocal, V.M.; Lucas, S.; González-Benito, G.; García-Cubero, M.T. Protein production in Spirulina platensis biomass using beet vinasse-supplemented culture media. Food Bioprod. Process. 2015, 94, 306-312. [CrossRef]

40. Rodolfi, L.; Zittelli, G.C.; Bassi, N.; Padovani, G.; Biondi, N.; Bonini, G.; Tredici, M.C. Microalgae for oil: Strain selection, induction of lipid synthesis and outdoor mass cultivation in a low-cost photobioreactor. Biotechnol. Bioeng. 2009, 102, 100-112. [CrossRef] [PubMed]

41. Illman, A.M.; Scragg, A.H.; Shales, S.W. Increase in Chlorella strains calorific values when grown in low nitrogen medium. Enzyme Microb. Technol. 2000, 27, 631-635. [CrossRef]

42. Dragone, G.; Fernandes, B.; Abreu, A.; Vicente, A.; Teixeira, J. Nutrient limitation as a strategy for increasing starch accumulation in microalgae. Appl. Energy 2011, 88, 3331-3335. [CrossRef]

43. Ling, J.; Nip, S.; Cheok, W.L.; de Toledo, R.A.; Shim, H. Lipid production by a mixed culture of oleaginous yeast and microalga from distillery and domestic mixed wastewater. Bioresour. Technol. 2014, 173, 132-139. [CrossRef] [PubMed]

44. Olguín, E.J.; Dorantes, E.; Castillo, O.S.; Hernández-Landa, V.J. Anaerobic digestates from vinasse promote growth and lipid enrichment in Neochloris oleoabundans cultures. J. Appl. Phychol. 2015, 27, 1813-1822. [CrossRef]

45. Pérez-García, O.; Escalante, F.; de-Bashan, L.; Bashan, Y. Heterotrophic cultures of microalgae: Metabolism and potential products. Water Res. 2011, 45, 11-36. [CrossRef] 
46. Demirbas, M.F. Biorefineries for biofuel upgrading: A critical review. Appl. Energy 2009, 86, $151-161$. [CrossRef]

47. Bhatt, A.K.; Bhatia, R.K.; Thakur, S.; Rana, N.; Sharma, V.; Rathour, R.K. Fuel from waste: A review on scientific solution for waste management and environment conservation. In Prospects of Alternative Transportation Fuels; Singh, A.P., Agarwal, R.A., Agarwal, A.K., Dhar, A., Shukla, M.K., Eds.; Springer: Singapore, 2018; pp. 205-233.

48. Roversi, R.; Cumo, F.; D’Angelo, A.; Pennacchia, E.; Piras, G. Feasibility of municipal waste reuse for building envelopes for near zero-energy buildings. WIT Trans. Ecol. Environ. 2017, 224, 115-125. [CrossRef]

49. De Santoli, L.; Basso, G.L.; Garcia, D.A.; Piras, G.; Spiridigliozzi, G. Dynamic simulation model of trans-critical carbon dioxide heat pump application for boosting low temperature distribution networks in dwellings. Energies 2019, 12, 484. [CrossRef]

50. D'Souza, F.M.L.; Kelly, G.J. Effects of a diet of a nitrogen-limited alga (Tetraselmis suecica) on growth, survival and biochemical composition of tiger prawn (Penaeus semisulcatus) larvae. Aquaculture 2000, 181, 311-329. [CrossRef]

51. Chen, F. High cell density culture of microalgae in heterotrophic growth. Trends Biotechnol. 1996, 14, 421-426. [CrossRef]

52. Whitton, R.; Ometto, F.; Pidou, M.; Jarvis, P.; Villa, R.; Jefferson, B. Microalgae for municipal wastewater nutrient remediation: Mechanisms, reactors and outlook for tertiary treatment. Environ. Technol. Rev. 2015, 4, 133-148. [CrossRef]

53. Christenson, L.; Sims, R. Production and harvesting of microalgae for wastewater treatment, biofuels, and bioproducts. Biotechnol. Adv. 2011, 29, 686-702. [CrossRef] [PubMed]

54. Zuorro, A.; Maffei, G.; Lavecchia, R. Reuse potential of artichoke (Cynara scolimus L.) waste for the recovery of phenolic compounds and bioenergy. J. Clean. Prod. 2016, 111, 279-284. [CrossRef]

(C) 2019 by the authors. Licensee MDPI, Basel, Switzerland. This article is an open access article distributed under the terms and conditions of the Creative Commons Attribution (CC BY) license (http://creativecommons.org/licenses/by/4.0/). 